\title{
Leucine-enriched essential amino acid supplementation in mechanically ventilated trauma patients: a feasibility study
}

\author{
L. Wandrag ${ }^{1,2^{*}}$ D, S. J. Brett ${ }^{3}$, G. S. Frost ${ }^{1}$, M. To ${ }^{1}$, E. Alves Loubo ${ }^{1}$, N. C. Jackson ${ }^{4}$, A. M. Umpleby ${ }^{4}$, \\ V. Bountziouka ${ }^{5}$ and M. Hickson ${ }^{1,6}$
}

\begin{abstract}
Background: Critically ill patients lose up to $2 \%$ of muscle mass per day. We assessed the feasibility of administering a leucine-enriched essential amino acid (L-EAA) supplement to mechanically ventilated trauma patients with the aim of assessing the effect on skeletal muscle mass and function.

Methods: A randomised feasibility study was performed over six months in intensive care (ICU). Patients received $5 \mathrm{~g}$ L-EAA five times per day in addition to standard feed (L-EAA group) or standard feed only (control group) for up to 14 days. C-reactive protein, albumin, IL-6, IL-10, urinary 3-MH, nitrogen balance, protein turnover ([1-13C] leucine infusion), muscle depth change (ultrasound), functional change (Katz and Barthel indices) and muscle strength Medical Research Council (MRC) sum score to assess ICU Acquired Weakness were measured sequentially.
\end{abstract}

Results: Eight patients (9.5\% of screened patients) were recruited over six months. L-EAA doses were provided on 91/ 124 (73\%) occasions. Inflammatory and urinary marker data were collected; serial muscle depth measurements were lacking due to short length of stay. Protein turnover studies were performed on five occasions. MRC sum score could not be performed as patients were not able to respond to the screening questions. The Katz and Barthel indices did not change. L-EAA delivery was achievable, but meaningful functional and muscle mass outcome measures require careful consideration in the design of a future randomised controlled trial.

Conclusion: L-EAA was practical to provide, but we found significant barriers to recruitment and measurement of the chosen outcomes which would need to be addressed in the design of a future, large randomised controlled trial.

Trial registration: ISRCTN Registry, ISRCTN79066838. Registered on 25 July 2012.

Keywords: Muscle wasting, Essential amino acids, Leucine, Muscle ultrasound, Critically ill, Nitrogen balance, Protein turnover, Mechanical ventilation, Trauma

\section{Background}

Critically ill patients lose up to $2 \%$ of muscle volume per day over the first 10 days $[1,2]$ and physical disability has been identified up to five years after Intensive Care Unit (ICU) admission in severe lung injury patients [3]. Minimising muscle wasting is crucial to optimise recovery. In elderly institutionalised patients, leucine-enriched

\footnotetext{
* Correspondence: I.wandrag@imperial.ac.uk

${ }^{1}$ Nutrition and Dietetic Research Group, Department of Investigative

Medicine, Imperial College London, London, UK

2Department of Nutrition \& Dietetics, Guy's \& St Thomas' NHS Foundation

Trust, London, UK

Full list of author information is available at the end of the article
}

essential amino acid (L-EAA) supplementation twice daily improved nutritional status, muscle function and physical performance [4]. Leucine supplementation increased muscle protein synthesis in elderly individuals in the short term $[5,6]$. This type of supplement has not yet been studied in the critically ill, yet a recent review suggested it warranted further investigation [7].

The aims of this feasibility study were fourfold:

1. To determine the expected rate of recruitment for a future randomised controlled trial (RCT).

(C) The Author(s). 2019 Open Access This article is distributed under the terms of the Creative Commons Attribution 4.0 International License (http://creativecommons.org/licenses/by/4.0/), which permits unrestricted use, distribution, and reproduction in any medium, provided you give appropriate credit to the original author(s) and the source, provide a link to the Creative Commons license, and indicate if changes were made. The Creative Commons Public Domain Dedication waiver (http://creativecommons.org/publicdomain/zero/1.0/) applies to the data made available in this article, unless otherwise stated. 
2. To establish whether a mechanically ventilated trauma population would represent a feasible patient population to study for this intervention.

3. To determine whether it was possible to routinely deliver a L-EAA supplement in ICU patients.

4. To test the feasibility of measuring muscle mass, protein turnover, strength and physical function outcomes for a future RCT.

\section{Methods}

This prospective randomised feasibility study was conducted at a large London teaching hospital in the adult ICU from May 2012 to December 2012.

Inclusion criteria were: age > 18 years; admission for trauma (head or multiple trauma); expected to be mechanically ventilated for $>48 \mathrm{~h}$; within $72 \mathrm{~h}$ of ICU admission. Exclusion criteria were: non-trauma admissions; pregnant or lactating; contraindication to enteral feeding or a pre-existing condition where muscle wasting was exhibited, i.e. patients with congestive cardiac failure, neuromuscular disorders, end-stage renal failure, chronic obstructive pulmonary disease and liver cirrhosis. Trauma patients were selected as these patients are generally younger, fitter and usually present with fewer co-morbidities than other ICU cohorts, thereby representing a more homogenous cohort. The onset of injury can also usually be identified enabling baseline representation of muscle mass and the anticipated length of stay for head or multiple trauma is often significant.

An independent research nurse performed the randomisation of patients via computer-generated schedule to either standard care (control group) or the L-EAA supplement. A branched-chain amino acid ratio for valine : leucine : isoleucine of $1: 5: 1$ was used based on a previous study where additional leucine was shown to promote muscle protein synthesis [8]. In addition to standard enteral feeding, patients in the treatment group received a 5-g L-EAA powder dissolved in $100 \mathrm{~mL}$ of sterile water five times per day via the enteral feeding tube. This was continued for up to 14 days. Control patients received standard enteral feeding via ICU protocol. No placebo was used since at the time of study design the manufacturer could not supply an appropriate product. The study was not blinded as the researcher was also measuring the outcome.

\section{Study outcome measures}

The following measures of feasibility were collected: the number of patients recruited compared with those screened; compliance with administration of the L-EAA dose; and the number and reason for missed outcome measures (inflammatory markers, cytokines, nitrogen balance studies, muscle depth change, protein turnover and functional outcome measures).
Candidate outcome measures to determine rates of muscle wasting, protein turnover, strength and physical function were explored to examine their feasibility in a large RCT. These were muscle depth change on ultrasound, whole-body protein turnover using an intravenous (i.v.) infusion of 1-13C leucine, Katz and Barthel indices to assess functional change and the Medical Research Council (MRC) sum score to assess ICU-acquired weakness (ICU-AW).

C-reactive protein $(\mathrm{CRP})(\mathrm{mg} / \mathrm{L})$, albumin $(\mathrm{g} / \mathrm{L})$, interleukin (IL)-6 (pg/mL) and IL-10 (pg/mL) levels were measured serially on days $1,3,7$ and 14 of the study. Cytokines were measured from plasma samples and analysed via enzyme-linked immunosorbent assay (ELISA) using ELISA grade streptavidin HRP and human IL-10 and IL-6 duosets obtained from R\&D systems, Oxford, UK.

Muscle depth change $(\mathrm{cm})$ was measured on alternate days throughout the ICU admission. The protocol has been described by Reid et al. [2], but, in brief, includes taking muscle measurements from the bicep, forearm and thigh and adding the measurements together to obtain a total muscle depth $(\mathrm{cm})$. Ultrasound measurements were undertaken using a Sonosite $M$ Turbo ${ }^{\mathrm{TM}}$ ultrasound machine with a $5-\mathrm{MHz}$ linear array transducer (Sonosite Ltd., Hitchin, Hertfordshire, UK).

Urinary urea $(\mathrm{mmol} / 24 \mathrm{~h})$ and urinary 3-methylhistidine $(\mu \mathrm{mol} / 24 \mathrm{~h})$ samples were collected on study days $1,3,7$ and 14. 3-Methylhistidine (3-MH) i was used as a surrogate marker for skeletal muscle breakdown. An amino acid analyser with cation exchange chromatography (JEOL UK Ltd., Hertfordshire, UK) was used to analyse samples with ninhydrin detection and one inferred standard. Urine urea was measured by a kinetic urease using an Abbott Architect assay with Abbott reagents (Abbott, Maidenhead, UK).

Nitrogen balance (= nitrogen in - nitrogen out) (g/ day) was calculated using both the British Dietetic Association's Parenteral and Enteral Nutrition Group (PENG) recommended equation and the Deacon equation [9] (see Additional file 1).

Katz and Barthel indices were used to assess activities of daily living data. The MRC sum score was used upon awakening and at discharge from ICU as a measure of strength and to determine presence of ICU-AW as recommended by International Guidelines [10].

To measure protein turnover a primed intravenous infusion of $1-13 \mathrm{C}$ Leucine $1 \mathrm{mg} / \mathrm{kg} ; 1 \mathrm{mg} / \mathrm{kg} / \mathrm{h}$ (MassTrace, Somerville, MA, US) was administered for $3 \mathrm{~h}$ as previously described [11] on days 1, 3, 7 and 14. Regular blood and breath samples were taken for the measurement of the enrichment of alpha-ketoisocaproic acid $(\alpha-\mathrm{KIC})$, the concentration of leucine and the enrichment of expired $\mathrm{CO}_{2}$ at $-10 \mathrm{~min}, 0 \mathrm{~min}, 150 \mathrm{~min}$ (steady state), $160 \mathrm{~min}, 170 \mathrm{~min}$ and $180 \mathrm{~min}$. Blood 
samples were taken from indwelling arterial catheters and breath samples were collected from the expiratory port of the ventilator (Servo 300, Siemens, Berlin, Germany or Servo I, Maquet, Sweden) via a Douglas bag with flow meter attached. Enteral feed was stopped $5 \mathrm{~h}$ before and during the $3 \mathrm{~h}$ of the protein turnover study (see Additional file 1 for protocol and laboratory analysis).

Continuous variables are shown as median (95\% confidence interval) due to small sample size; categorical variables are shown as frequencies (\%). Descriptive statistics were performed using SPSS V.20 (IBM Corp. 2011).

\section{Results}

From 1 May 2012 until 31 December 2012, 324 patients were admitted to intensive care. Eighty-four patients (25.9\%) were major trauma admissions and 8 (9.5\%) of these patients were recruited to this feasibility study. Patient recruitment is illustrated in Fig. 1.

Demographic data are summarised in Table 1.

The feasibility of data collection is described in Table 2. Muscle ultrasound and protein turnover data collection were much lower than anticipated because patients were transferred back to referring hospitals earlier than anticipated. The Katz and
Table 1 Demographic data of trauma ICU patient cohort

\begin{tabular}{lll}
\hline Demographic factors & Control $(n=4)$ & L-EAA $(n=4)$ \\
\hline Age (years) & $60(28-99)$ & $53(19-58)$ \\
Sex, $\mathrm{n}(\%$ men) & $2(50)$ & $4(100)$ \\
BMI $\left(\mathrm{kg} / \mathrm{m}^{2}\right)$ & $23(20-28)$ & $25(21-28)$ \\
APACHE II (0-71) ${ }^{\text {a }}$ & $14(13-20)$ & $15(11-22)$ \\
Injury Severity Score (0-75) $^{\mathrm{b}}$ & $27(13-34)$ & $42(20-50)$ \\
Diagnosis, n (\%) & & \\
$\quad$ Multiple trauma (no TBI) & $1(12.5)$ & $1(12.5)$ \\
$\quad$ TBI only & $1(12.5)$ & $1(12.5)$ \\
$\quad$ Trauma including TBI & $2(25)$ & $2(25)$ \\
ICU LOS (days) & $5(2-6)$ & $10(8-14)$ \\
Hospital LOS (days) & $15(4-29)$ & $14(8-30)$ \\
\hline
\end{tabular}

L-EAA leucine-enriched essential amino acid, IQR interquartile range, $B M I$ body mass index, APACHE II Acute Physiology and Chronic Health Evaluation II, TBI traumatic brain injury, ICU Intensive Care Unit, LOS length of stay

Continuous variables shown as median ( $95 \%$ confidence intervals); categorical variables shown as frequencies (\%)

${ }^{a} H i g h e r$ APACHE I scores indicate greater disease severity and correspond with risk of death

${ }^{b}$ Injury Severity Score $>15$ is defined as major trauma

Barthel indices remained at zero for all patients throughout the study and are considered inappropriate for future use in ICU populations. Manual

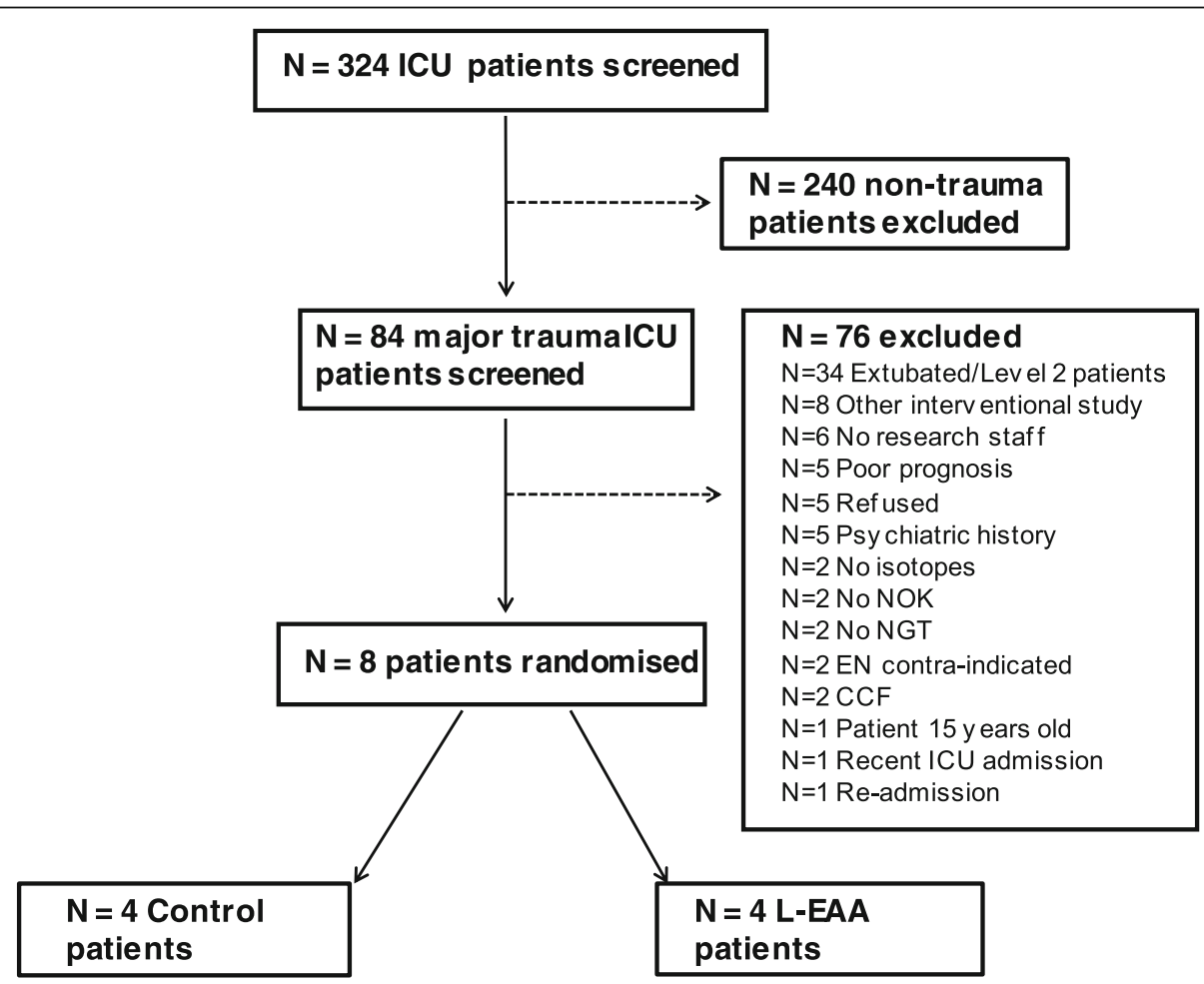

Fig. 1 Patient recruitment for the feasibility study. CCF: congestive cardiac failure; EN: enteral nutrition; ICU: intensive Care Unit; L-EAA leucineenriched essential amino acid, NGT nasogastric tube, NOK next-of-kin. No research staff --> no reserach staff for recruitment and enrolment; recent ICU admission- other hospital; re-admission - same hospital ICU 
Table 2 Feasibility of outcome measures, planned versus achieved measurements

\begin{tabular}{|c|c|c|c|c|c|c|}
\hline \multirow{2}{*}{$\begin{array}{l}\text { Outcome measure } \\
\text { Patients recruited }\end{array}$} & \multirow{2}{*}{$\begin{array}{l}\text { Target } \\
(\%) \\
>30\end{array}$} & \multirow{2}{*}{$\begin{array}{l}\text { Achieved } \\
(\%) \\
\\
\begin{array}{l}9.5 \% \text { patients } \\
\text { recruited }\end{array}\end{array}$} & \multirow{2}{*}{$\begin{array}{l}\text { Comment } \\
\text { Lower than anticipated }\end{array}$} & $\begin{array}{l}\text { Control }(n= \\
\text { Results as } r\end{array}$ & $\begin{array}{l}=4) \\
\text { ange }\end{array}$ & \multirow{2}{*}{$\begin{array}{l}\text { L-EAA } \\
(n=4) \\
\text { Results } \\
\text { as } \\
\text { range } \\
-\end{array}$} \\
\hline & & & & - & & \\
\hline L-EAA supplement & $>70$ & $\begin{array}{l}73 \% \text { doses } \\
\text { given }\end{array}$ & Unable to give due to Gl intolerance & - & & - \\
\hline \multirow[t]{4}{*}{$\begin{array}{l}\text { Inflammatory markers and } \\
\text { cytokines }\end{array}$} & \multirow[t]{4}{*}{$>90$} & \multirow[t]{4}{*}{$\begin{array}{l}\text { 100\% samples } \\
\text { taken }\end{array}$} & \multirow[t]{4}{*}{ All required samples were taken } & $\begin{array}{l}\text { CRP }(\mathrm{mg} / \\
\mathrm{L})\end{array}$ & $\begin{array}{l}2- \\
312\end{array}$ & $\begin{array}{l}42.7- \\
262\end{array}$ \\
\hline & & & & $\begin{array}{l}\text { Serum } \\
\text { albumin } \\
(\mathrm{g} / \mathrm{L})\end{array}$ & $\begin{array}{l}22- \\
30\end{array}$ & 29-39 \\
\hline & & & & $\begin{array}{l}\mathrm{IL}-6(\mathrm{pg} / \\
\mathrm{mL})\end{array}$ & $\begin{array}{l}11.4- \\
141\end{array}$ & $9-78.5$ \\
\hline & & & & $\begin{array}{l}\mathrm{IL}-10(\mathrm{pg} / \\
\mathrm{mL})\end{array}$ & $\begin{array}{l}0- \\
137\end{array}$ & $0-2100$ \\
\hline \multirow[t]{2}{*}{ Urine samples (u-urea, 3-MH) } & \multirow[t]{2}{*}{$>80$} & \multirow[t]{2}{*}{$\begin{array}{l}81 \% \text { samples } \\
\text { taken }\end{array}$} & \multirow[t]{2}{*}{$\begin{array}{l}\text { CRRT expected in some patients hence } \\
>80 \% \text { planned } \\
\text { No misplaced samples }\end{array}$} & $\begin{array}{l}\text { Urinary } \\
\text { urea } \\
\text { (mmol/ } \\
24 \mathrm{~h})\end{array}$ & $\begin{array}{l}55- \\
269\end{array}$ & $51-382$ \\
\hline & & & & $\begin{array}{l}3-\mathrm{MH} \\
(\mu \mathrm{mol} / 24 \\
\mathrm{h})\end{array}$ & $\begin{array}{l}174- \\
616\end{array}$ & $\begin{array}{l}144- \\
660\end{array}$ \\
\hline $\begin{array}{l}\text { Muscle depth via ultrasound (sum } \\
\text { of three sites, planned } \\
\text { measurement on alternate days) }\end{array}$ & $>90$ & $\begin{array}{l}50 \% \\
\text { measurements } \\
\text { completed }\end{array}$ & $\begin{array}{l}\text { Shorter LOS than anticipated } \\
\text { Fewer measurements recommended, } \\
\text { i.e. days } 1,7,10\end{array}$ & $\begin{array}{l}\text { Muscle } \\
\text { depth } \\
(\mathrm{cm})\end{array}$ & $\begin{array}{l}5.34- \\
12.36\end{array}$ & $\begin{array}{l}4.43- \\
11.93\end{array}$ \\
\hline Protein turnover study & $>80$ & $\begin{array}{l}31 \% \text { studies } \\
\text { completed }\end{array}$ & $\begin{array}{l}\text { Complex, time-consuming } \\
\text { Required } 3 \text { staff members for Douglas bag breath } \\
\text { collection method and blood sampling. Simpler } \\
\text { technique required, whole body vs muscle protein } \\
\text { turnover }\end{array}$ & $\begin{array}{l}\text { Protein } \\
\text { turnover } \\
(\mathrm{g} / 24 \mathrm{~h})\end{array}$ & 0 & $\begin{array}{l}-3.9 \text { to } \\
-1.73\end{array}$ \\
\hline Nitrogen balance (PENG, g/day) & $>80$ & $81 \%$ calculated & CRRT affecting urine sampling, urinary urea & \multicolumn{2}{|c|}{-10.6 to 7.4} & $\begin{array}{l}-7.95 \\
\text { to } 11\end{array}$ \\
\hline Nitrogen balance (Deacon, g/day) & $>80$ & $81 \%$ calculated & CRRT affecting urine sampling, urinary urea & \multicolumn{2}{|l|}{-6.2 to 7.4} & $\begin{array}{l}-3.3 \\
\text { to } 11.2\end{array}$ \\
\hline Katz and Barthel indices & $>90$ & $100 \%$ tested & Poor tests in this setting with substantial floor effect & \multicolumn{2}{|l|}{0} & 0 \\
\hline MRC sum score & $>90$ & $0 \%$ completed & $\begin{array}{l}\text { No patient passed initial MRC screening questions ( } 8 / 10 \\
\text { presented with traumatic brain injury) }\end{array}$ & \multicolumn{2}{|l|}{-} & - \\
\hline
\end{tabular}

CRP C-reactive protein, IL-6 interleukin 6, IL-10 interleukin 10, L-EAA leucine-enriched essential amino acid, Gl gastrointestinal, CRRT chronic renal replacement therapy, 3-MH 3-methylhistidine, LOS length of stay, MRC Medical Research Council, RFCSA rectus femoris cross-sectional area

strength testing could not be performed as patients were not able to respond appropriately to the screening questions.

\section{Discussion}

This study was designed to investigate the feasibility of undertaking a RCT providing a L-EAA supplement to critically ill trauma patients to determine the effect on muscle wasting and protein turnover. We found significant barriers to recruitment and to measurement of the chosen outcomes which would need to be addressed in the design of a future, large RCT. Recruitment was dependent on one researcher without $24 \mathrm{~h}$ availability. We also found the measurement of some outcomes and frequency thereof to be very intensive for each patient.

Specific recommendations for a future study include the following:

In terms of recruitment, a multicentre design should be considered, potentially as part of a trial group that enables enrolment in multiple sites nationally and/or internationally. The design of a future protocol should allow co-enrolment with other studies, where feasible. We would advise having multiple trained members of staff available to recruit over $24 \mathrm{~h}$, for seven days per week.

In terms of the population studied, the trauma population had some theoretical advantages, fewer 
co-morbidities, potentially fewer confounders and known onset of injury. However, the dynamic nature of this cohort was underestimated; they had multiple procedures, interventions, admissions to theatre and unexpected repatriation. This made data collection difficult for an intensive physiological study such as this. We would recommend not restricting recruitment to a specific type of ICU patient but including those who are expected to be ventilated for $>48 \mathrm{~h}$ and perhaps those patients with high nutritional risk.

Provision of a L-EAA supplement is possible in an ICU setting; however, minimising the number of doses from five times a day to twice daily may aid delivery without reducing any potential beneficial effect. Type and dose of amino acid supplement as well as the best phase of critical illness (acute, chronic, recovery phase) in which to provide this [12] still needs to be explored thoroughly in future studies. Protein supplementation in conjunction with physical activity or exercise may have the best synergistic effect [13]. The current NEXIS (Nutrition and Exercise in Critical Illness) Trial, ClinicalTrials.gov Identifier NCT03021902, in which intravenous amino acids is given alongside in-bed cycle ergometry, will aid to explore this synergistic effect.

In terms of outcome measures, we would suggest that a larger research team is required for such complex outcome measures as stable isotope measurement in ventilated patients. However, the number of staff performing muscle ultrasound measurements should be minimised due to the challenges of achieving good interrater reliability. Serial muscle ultrasound measurement over fewer data collection points, i.e. days 1 and 7, may be more sensible. A longer follow-up period would be required in a future amino acid dosing study to assess the post-ICU phase. Patients should be followed up into the ward and after the hospital admission so that longerterm functional outcome measures could be assessed. A mixture of nutritional, physical and functional outcome measures should be included in this type of study. Inflammatory markers and cytokine data were feasible to collect on most occasions. Urinary measurements were only missed due to renal replacement therapy. Serial muscle ultrasound measurement over fewer data collection points, i.e. days 1 and 7, may be more sensible.

The Katz and Barthel indices demonstrated substantial floor effects and were thus poor informers of functional change in critically ill patients. MRC sum score assessment is not advised in a majority head-injured trauma population. Functional assessment tools require piloting in future studies.

To our knowledge, this was the first study to assess the feasibility of using a L-EAA supplement in mechanically ventilated trauma patients. Outcome measures to assess protein turnover, muscle depth change and markers of protein breakdown in conjunction with functional outcome measures are not usually embedded into nutrition trials in the ICU. As such, this study should assist future investigators in considering which ICU patient population and outcome measures to study.

\section{Conclusion}

Amino acid supplementation is feasible in ventilated critically ill patients; however, this study had some major design limitations. Researchers need to consider the study population carefully, perhaps considering individual phenotypes and including patients with high nutritional risk, as well as the detailed clinical pathway. The intervention needs careful consideration for type, dose and timing in terms of phase of illness. Studying interventions both in the ICU and post-ICU phase may be most informative, while coupling amino acids with physical activity. Muscle mass, functional and quality of life outcome measures should be included in future studies.

\section{Additional file}

Additional file 1: Supplementary material [14]. (DOCX $44 \mathrm{~kb}$ )

\begin{abstract}
Abbreviations
3-MH: 3-Methylhistidine; CRP: C-reactive protein; ELISA: Enzyme-linked immunosorbent assay; ICU: Intensive Care Unit; ICU-AW: Intensive Care Unitacquired weakness; IL-10: Interleukin 10; IL-6: Interleukin 6; L-EAA: Leucineenriched essential amino acid; MRC: Medical Research Council; NEXIS trial: Nutrition and Exercise in Critically IIIness trial; PENG: Parenteral and Enteral Nutrition Group of the British Dietetic Association; RCT: Randomised controlled trial; a-KIC: Alpha-ketoisocaproic acid
\end{abstract}

\section{Acknowledgements}

The authors acknowledge support from the ICU research team at Kings College Hospital, London for assistance with screening of patients and for assistance with performing stable isotope studies in ventilated trauma patients, in particular Dr Phil Hopkins, Dr Stephanie Strachan and Dr Andre Vercueil.

\section{Authors' contributions}

LW, SJB, GSF and MH acquired funding and designed this study. LW performed data acquisition and analysis. VB assisted with statistical plan and data analysis. MT and EAL assisted with data acquisition, laboratory analysis of ELISA and interpretation of data. NCJ and AMU supervised stable isotope laboratory work and advised on protein turnover data. All authors were involved with final interpretation of data and have read and approved the final version of the manuscript.

\section{Funding}

LiesI Wandrag was funded by a National Institute for Health Research (NIHR), Clinical Doctoral Research Fellowship for this research project. This publication presents independent research funded by the National Institute for Health Research (NIHR). The research was further supported by the NIHR Comprehensive Biomedical Research Centre based at Imperial College Healthcare NHS Trust and Imperial College London. The views expressed are those of the author(s) and not necessarily those of the NHS, the NIHR or the Department of Health and Social Care. 


\section{Availability of data and materials}

The dataset used and analysed during the current study is available from the corresponding author on reasonable request.

\section{Ethics approval and consent to participate}

The Medicines and Healthcare Products Regulatory Agency confirmed this was not a trial of an investigative medicinal product and ethical approval was granted by the Camden \& Islington Research Ethics Committee (10/ H0722/40), trial registration: ISRCTN79066838. In line with the Mental Capacity Act 2005 for persons who lack capacity, agreement was sought from a personal or professional consultee. Retrospective consent was gained once a patient regained capacity.

\section{Competing interests}

The authors declare that they have no competing interests.

\section{Author details}

${ }^{1}$ Nutrition and Dietetic Research Group, Department of Investigative Medicine, Imperial College London, London, UK. ${ }^{2}$ Department of Nutrition \& Dietetics, Guy's \& St Thomas' NHS Foundation Trust, London, UK. ${ }^{3}$ Centre for Peri-operative Medicine and Critical Care Research, Imperial College Healthcare NHS Trust, London, UK. ${ }^{4}$ Department of Nutritional Science, University of Surrey, Guildford, UK. ${ }^{5}$ Statistical Support Service, Population, Policy and Practice Programme, Institute of Child Health, University College London, London, UK. ${ }^{6}$ Institute of Health and Community, University of Plymouth, Plymouth, Devon, UK.

Received: 25 April 2019 Accepted: 8 August 2019

Published online: 11 September 2019

\section{References}

1. Puthucheary ZA, McPhail MJ, Hart N. Acute muscle wasting among critically ill patients--reply. JAMA. 2014;311(6):622-3.

2. Reid $\mathrm{CL}$, Campbell IT, Little RA. Muscle wasting and energy balance in critical illness. Clin Nutr. 2004:23(2):273-80.

3. Herridge MS. The challenge of designing a post-critical illness rehabilitation intervention. Crit Care. 2011;15(5):1002.

4. Rondanelli M, Opizzi A, Antoniello N, Boschi F, ladarola P, Pasini E, et al. Effect of essential amino acid supplementation on quality of life, amino acid profile and strength in institutionalized elderly patients. Clin Nutr. 2011; 30(5):571-7.

5. Anthony JC, Anthony TG, Kimball SR, Jefferson LS. Signaling pathways involved in translational control of protein synthesis in skeletal muscle by leucine. J Nutr. 2001;131(3):856S-60S.

6. Katsanos CS, Kobayashi H, Sheffield-Moore M, Aarsland A, Wolfe RR. Aging is associated with diminished accretion of muscle proteins after the ingestion of a small bolus of essential amino acids. Am J Clin Nutr. 2005:82(5):1065-73

7. Wandrag L, Brett SJ, Frost G, Hickson M. Impact of supplementation with amino acids or their metabolites on muscle wasting in patients with critical illness or other muscle wasting illness: a systematic review. J Hum Nutr Diet. 2015;28(4):313-30.

8. Borsheim E, Bui QU, Tissier S, Kobayashi H, Ferrando AA, Wolfe RR. Effect of amino acid supplementation on muscle mass, strength and physical function in elderly. Clin Nutr. 2008;27(2):189-95.

9. Deacon A, Sherwood RA, Hooper J, Association for Clinical Biochemistry (Great Britain). Calculations in laboratory science. London: ACB Venture Publications; 2009.

10. Stevens RD, Dowdy DW, Michaels RK, Mendez-Tellez PA, Pronovost PJ, Needham DM. Neuromuscular dysfunction acquired in critical illness: a systematic review. Intensive Care Med. 2007;33(11):1876-91.

11. Carroll PV, Jackson NC, Russell-Jones DL, Treacher DF, Sonksen PH, Umpleby AM. Combined growth hormone/insulin-like growth factor I in addition to glutamine-supplemented TPN results in net protein anabolism in critical illness. Am J Physiol Endocrinol Metab. 2004; 286(1):E151-7.

12. Wischmeyer PE, Puthucheary Z, San Milla I, Butze D, Grocott MPW. Curr Opin Crit Care. 2017;23:269-78. https://doi.org/10.1097/MCC. 0000000000000431.
13. Breen $L$, Phillips $S M$. Nutrient interaction for optimal protein anabolism in resistance exercise. Curr Opin Clin Nutr Metab Care. 2012;15(3):226-32. https://doi.org/10.1097/MCO.0b013e3283516850.

14. Bear DE, Wandrag L, Merriweather JL, Connolly B, Hart N, Grocott MPW. Enhanced Recovery After Critical IIIness Programme Group (ERACIP) investigators. The role of nutritional support in the physical and functional recovery of critically ill patients: a narrative review. Crit Care. 2017;21(1):226. https://doi.org/10.1186/s13054-017-1810-2 Review.

\section{Publisher's Note}

Springer Nature remains neutral with regard to jurisdictional claims in published maps and institutional affiliations.
Ready to submit your research? Choose BMC and benefit from:

- fast, convenient online submission

- thorough peer review by experienced researchers in your field

- rapid publication on acceptance

- support for research data, including large and complex data types

- gold Open Access which fosters wider collaboration and increased citations

- maximum visibility for your research: over $100 \mathrm{M}$ website views per year

At $\mathrm{BMC}$, research is always in progress.

Learn more biomedcentral.com/submissions 